\title{
札幌市のアーバンフリンジを事例とした景観評価
}

\section{Landscape Evaluation of Urban Fringes in Sapporo City, northern Japan}

吉田惠介* 高木寛子* ${ }^{*}$ 矢部和夫* ${ }^{*}$ 浅川昭一郎 ${ }^{* *}$

Keisuke YOSHIDA Hiroko TAKAGI Kazuo YABE Shoichiro ASAKAWA

摘要：札幌市内に分布する低地と丘陵地の 2 地区で、アーバンフリンジを事例とした景観評価を行っ た。レパートリーグリッド発展法の結果. 2地区とも「緑の多さ」が好ましい景観の評価項目であっ た。またSD 法の結果を因子分析したところ，4つの因子軸が抽出され 3 つが評価軸だった。3つの 評価軸は特有の景観構成要素と有意な相関を示した：快適性軸-低木（正相関），開放性軸-山（正）・ 荒地 (正) - 人工物 (負), 特徵性軸-高木 (正) - 住宅 (負) - 雑草地 (負)。又, 景観の総合評価 である嗜好度に対して，快適性因子が最も強い影響を持っていた。以上のことから，景観の総合評価 には緑量と低木との相関があることが明らかになった。

\section{1.はじめに}

近年の市街地のスプロール化に伴い，市街化区域から市街化調 整区域にかかる区域であるアーバンフリンジ（市街化縁辺部）に 広がる景観は，市街地と農林地が隣接し，これらが混在化してい るために多くの問題点を含んでいる"。札幌市においても，都心 からの距離別人口を見ると, 都心の人口減少, 郊外地の人口増加 が顕著でありスプロール化が進行している2゙。このような地域で は将来的に「安定した土地利用」を実現させる必要があり ${ }^{3)}$ ，適 正な景観評価・分析方法に基づき, 最終的には良好な景観整備の 方向性を明確化する必要がある。

市街地や自然地の人工物を対象にした景観把握については多く の研究が見られるが，自然物と人工物が混在しているアーバンフ リンジの景観を対象とした研究は少ない。李・進士は都市農地景 観のイメージを説明する因子として審美性・親密性・情緒性の 3 つをあげ，農村農地が都市農地に比べて全体的に高い評価を受け ていることを明らかにしだ)。また, Asakawaらは, アーバン フリンジの景観イメージには空間性・自然性・特異性の 3 因子が 存在し，好ましさや自然性の評価に農地の状況が強く関与してい ることを示した ${ }^{5)}$ 。一方グアナン・吉田やアリスティムニョ・吉 田は具体的な場所，地域等について景観評価を行い，景観の選好 や施設整備要望等について調査を行い, 緑の多い歴史的文化財, 河川等に対する意識を明らかにした ジにおいて景観整備を行う際の景観構成要素への配慮点や景観評 価基準という視点から言及したものはみられない。

本研究では，1）アーバンフリンジの景観をレパートリーグリッ 卜発展法によってその評価構造を解明し， 2 ）SD 法による因子 分析によって因子軸を求め，3）各因子軸と相関を持つ景観構成 要素を抽出する。

\section{2. 研究対象地}

明治時代から始まった札幌市の市街地の拡大は, 時代の変遷に 沿って，都心から外側へと同心円的であった（図一1）。また札 幌市の自然及び景観特性は扇状地, 低地, 丘陵地之山地の 4 つの 単位に区分され, 西半分は丘陵地が分布しており, 北東部に低地, 南東部に丘陵地，中央部に扇状地がそれぞれ分布している ${ }^{8)}$ 。本 研究では札幌市のアーバンフリンジの中から，人口増加率が高く， 農地面積が多く見られ，一部には防風林も残されているが平坦地
のため視認されにくい北東部の低地郊外地区（A地区 : 新琴似, 新川）之住宅地開発が進んでいる丘陵地で 2 次林が多く残されて いる南東部の丘陵郊外地区（B地区 : 駒岡, 常盤, 石山）の二地 区を対象地にした。

\section{3. 調查方法}

\section{(1) 詈観代表写真の抽出}

1998 年 10 月 16 日，B地区において，この地域の混在化した 土地利用の組み合わせが多く入るように, 約 $500 \mathrm{~m}$ 間隔で設置し た 33 地点において，それぞれの中心点から 6 方向（360 度）の 写真を撮影した。なお，A地区については, 同様の方法ですでに 1996年 8 月14，19日に38地点で撮影された景観写真を使用した ${ }^{9)}$ 。

次に, 得られた景観写真（A地区 : 228 枚, B地区 198 枚）か ら, 類似した景観構成要素からなる写真を整理し, A地区 92 枚, B 地区 96 枚を選択し，地区毎に札幌市立高等専門学校の 4,5 年生 25 名による写真の任意分類実験を行った。この結果から写 真間の類似度を求め, ユークリッド距離によるWord 法によっ てクラスター分析を行った。次に, 各小クラスターから一枚ずっ 写真を選定した結果, A地区 13 枚, B地区 14 枚の景観代表写真 が得られた。

\section{（2）異なる被験者グループ間の景観の嗜好度}

性質が異なる被験者グループ間での評価の差異の有無を把握す るために, 各地区の景観代表写真について, 総合景観評価項目で ある嗜好度による分類実験を行った。被験者は, 学生 15 人（男 4 人, 女 11 人), 専門家 15 人（男 7 人, 女 8 人）であった。嗜

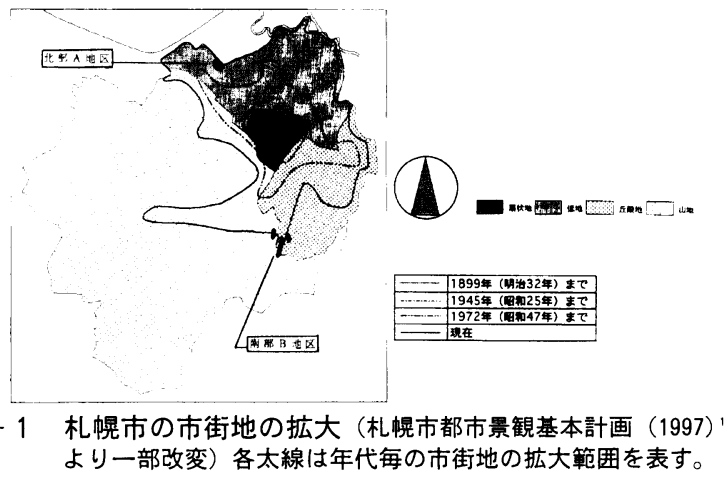

“札幌市立高等専門学校インダストリアルデザイン学科 “北海道大学大学院農学研究科 
好度の違いによって分類された写真の枚数が正規分布に従うよう にするために A 地区では，好き 6 枚，やや好き 22 枚，普通 36 枚, やや嫌い 22 枚之嫌い 6 枚の五段階に分類させ，また B 地区 も同様に，それぞれ 7 枚, 23 枚, 36 枚, 23 枚と 7 枚に分類させ た。学生と専門家間や性別での写真に対する嗜好度の差異に対し て 検定を行った。

\section{（3）評価項目と評価項目間の関係}

各地区の景観に対する評価項目之評価項目間の関係を把握する ために, 被験者（学生 14 人, 専門家 14 人) に対し, 景観代表写 真についてレパートリーグリッド発展手法を実施しだ110\%。

(4) 景観イメージ分析

各景観代表写真について, SD 法により景観イメージを把握し た。使用した形容詞対は，既往論文ですでに使用されたものと今 回のレパートリーグリッド発展法で頻出度の高かったものから選 択された 16 形容詞対であった（表一 1$)^{499111}$ 。各形容詞対に対し て七段階評価実験を行った。被験者は, 学生 20 人と専門家 11 人 （男 15 人，女 16 人）の 31 人であった。

表ー 1 SD 法で使用した形容詞対

\begin{tabular}{|c|c|c|c|}
\hline *美しい & 見苦しい & *広がりのある & 狭苦しい \\
\hline 都会的な & 田国的な & 不調和な & 調和した \\
\hline 単純な & 多様な & 悪い & 良い \\
\hline `まとまりのある & まとまりのある & ${ }^{\star}$ 自然的な & 人工的な \\
\hline 近くに住みたい & - 近くに住みたくない & 親しみのある & 親しみのない \\
\hline リラックスした & $\begin{array}{ll}\text { - } & \text { 䜿張した } \\
\end{array}$ & ^落ち着きのある & - 落ち着きのない \\
\hline 特徵のある & 平凡な & 好き & 嫌い \\
\hline `棶然とした & 整然とした & *快適な & 不快な \\
\hline
\end{tabular}

SD 法による集計結果から, 総合景観評価項目 (嗮好度 : 好き一 嫌い）を除く各形容詞対間の相関係数行列を求め主成分分析を行っ た。この結果得られた固有值 1 以上の 4 主成分軸についてバリマッ クス回転を行った。次に, 総合景観評価項目 (嗜好度) を目的変 数に設定し, 因子軸を説明変数として重回帰分析を行い, 各因子 軸の説明力を検定した。

（5）景観因子と景観構成要素の関連性

各景観代表写真を景観構成要素に分け, 電子天秤を使用し重量 を量り，それぞれの重量比率（\%)を算出した。景観写真の撮影

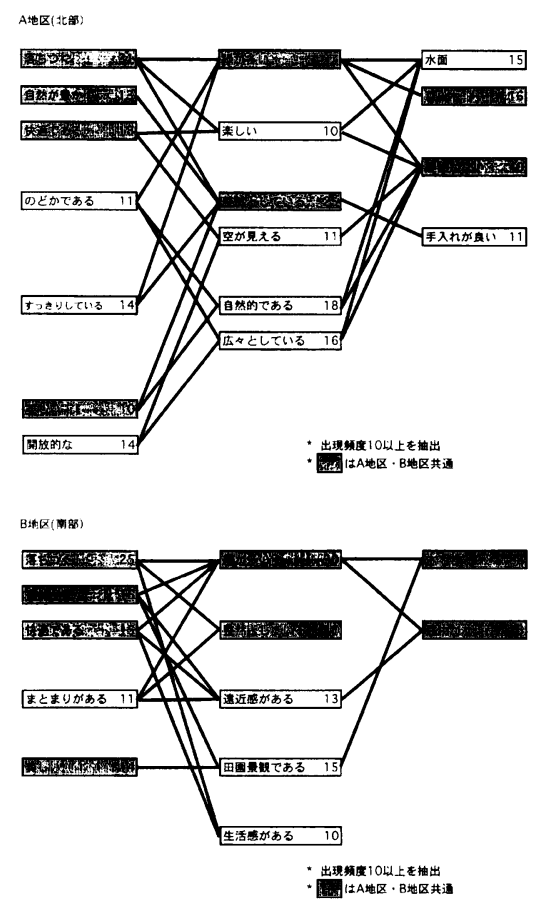

図ー２レパートリーグリッド発展法結果
角度の相違などによる本来の緑量と写真上での緑量の相違につい ては, 各撮影点から 360 度の視野に様々な景観構成要素が入って いると仮定し, クラスター分析により地域の代表的な景観構成要 素と緑量が含まれる写真を選択した。次に, 得られた景観構成要 素毎の重量比率を $\arcsin$ 変換した後, これを景観構成要素別の 面積比率とし，各因子軸との相関係数を求めた。

景観構成要素の分類は，アーバンフリンジの景観に関する既往 論文による要素と, 今回のレパートリーグリッド発展法から得ら れた頻出度の高かった要素から, 17 項目に設定した : 空, 山, 水 面, 高木樹木 (高さ $3 \mathrm{~m}$ 以上), 低木樹木 (高さ $3 \mathrm{~m}$ 末満), 畑, 荒地, 住宅, 農業施設, 自然道路, 舗装道路, 工業施設, 人工物 (看板, 資材など), 駐車場, 雑草地, 芝生とその他 ${ }^{9}$ 。統計解析には統 計ソフトSystat7.0を用いた。なお, 被写体の種類や近景遠景の 相違を同一評価軸で評価することは問題が残るが，レパートリー グリッド発展法の評価項目の結果では一部建物を除きそれらの影 響は見られなかったため,ここではそれらの区別は行わなかった。

\section{4. 結果}

\section{（1）異なるグループ間の景観の嗜好度}

A 地区において学生一専門家間で有意差の見られた代表景観写 真の割合は, $15.3 \%$ あり, 男女間でも同じ割合であった。B地 区では, 学生-専門家間, 男女間とあ有意差のある写真はなかっ た。このように有意差のみられた写真の割合は小さく, グループ 間での反応の差異は少ないと判断できた。

\section{(2) 景観評価項目と評価項目間の関係}

レパートリーグリッド発展法の結果 (㘡一-2), 両地区共に好 ましい景観の主な評価項目は「緑の多さ」であり, なぜ緑が多い と良いのかという理由（上位評価項目）として「落ちつく」とい う答が最も多かった。地区別ではA地区では「すっきりする」が あげられ，B地区では「自然が豊か」「「快適である」ことがあげ られた。この他, A地区の特徴としては「開放的な」,「のどかで ある」ことが多く，これに対しB地区では「まとまりがある」こ 表一 2 SD 法による因子分析の結果。

（因子負荷量の絶対值が 0.4 以下のものは省略。）

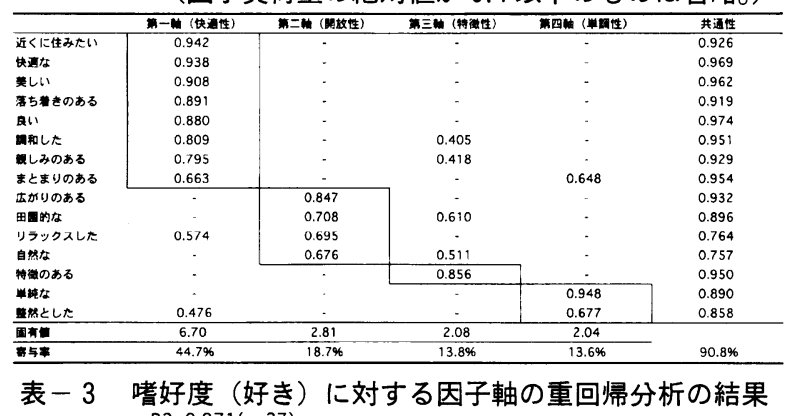

\begin{tabular}{|c|c|c|c|}
\hline & 回州保数 & (骤萑回禺倸数) & $\mathrm{p}$ 值 \\
\hline 定数 & 3.896 & & 0.000 \\
\hline 第一軸（快道性） & 0.442 & $(0.843)$ & 0.000 \\
\hline 第二醋放性） & 0.210 & $(0.401)$ & 0.000 \\
\hline 第三粙（特徵性） & 0.140 & $(0.267)$ & 0.000 \\
\hline 第四動（單調性） & -0.005 & $(-0.009)$ & 0.858 \\
\hline
\end{tabular}

\begin{tabular}{|c|c|c|c|c|}
\hline 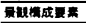 & 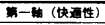 & 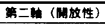 & 第三（特流性） & 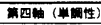 \\
\hline 䭪 & 0.391 & 0.287 & -0.351 & 0.150 \\
\hline 山 & 0.123 & $0.426^{*}$ & -0.319 & 0.105 \\
\hline 水面 & 0.263 & 0.179 & 0.050 & -0.114 \\
\hline 高末 & 0.131 & 0.106 & $0.433^{*}$ & -0.104 \\
\hline 但末 & $0.581^{* *}$ & -0.051 & 0.262 & -0.139 \\
\hline 㚼 & 0.169 & -0.042 & 0.091 & 0.370 \\
\hline 住毛 & 0.131 & -0.379 & $-0.433^{*}$ & -0.107 \\
\hline 自䓡道 & -0.034 & 0.062 & -0.073 & -0.189 \\
\hline 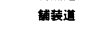 & -0.129 & -0.328 & .0 .187 & -0.171 \\
\hline 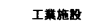 & -0.062 & -0.038 & -0.070 & -0.089 \\
\hline 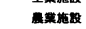 & -0.086 & 0.217 & 0.101 & 0.106 \\
\hline 人工物 & -0.129 & $-0.495 * *$ & -0.040 & -0.137 \\
\hline 掌地 & .0 .218 & $0.492^{\star *}$ & 0.085 & -0.099 \\
\hline 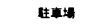 & -0.253 & 0.237 & -0.364 & -0.075 \\
\hline 拜电 & -0.130 & 0.318 & $-0.408^{*}$ & 0.004 \\
\hline ₹生 & 0.117 & 0.005 & 0.096 & 0.080 \\
\hline
\end{tabular}


とが出現した。また好ましい景観を感じる具体的な理由（下位評 価項目）は，両地区共に「建物がない」ことや「木・森がある」 ことが多く,この他に A地区にだけ「水面がある」「手入れが良 い」ことがみられた。

\section{（3）景観イメージの分析とその評価}

因子分析の結果, 四つの景観因子軸が抽出された（表－2）。 第一軸（寄与率 $44.7 \%$ ）は，「近くに住みたい」，「快適な」，「美 しい」,「落ち着きのある」,「良い」,「調和した」と「親しみのあ る」が最大の因子負荷量值を示した。このためこの軸を「快適性 因子」と名付けた。また「まとまりのある」は第一軸ばかりでなく， 第四軸に対してあ大きな負荷量值を示した。また第二軸（寄与率 18.7\%）は，「広がりのある」「田園的な」，「リラックスした」 と「自然な」が最大の負荷量值を示したのでこの軸を「開放性因 子」と命名した。第三軸は単独で最大の負荷量値を示した「特徴 のある」から「特徵性因子」と命名した。第四軸（寄与率 13.6\%) は「単純な」と「整然とした」が最大の負荷量值を示し たので「単調性因子」と命名した。

次に総合景観評価項目である嗜好度に対して各因子軸の因子得 点を重回帰分析した (表 -3 )。この結果, 景観の嗜好度に対し, 快 適性因子が最も強い，次に開放性因子と特徴性因子の順にそれぞ れ有意な影響力を持っていた。なお，単調性因子は有意な影響力 を持たなかった。以上の結果から，景観の嗜好度については快適 性因子軸, 開放性因子軸と特徵性因子軸の 3 つが評価軸であった。

（4）景観イメージと景観構成要素との相関性

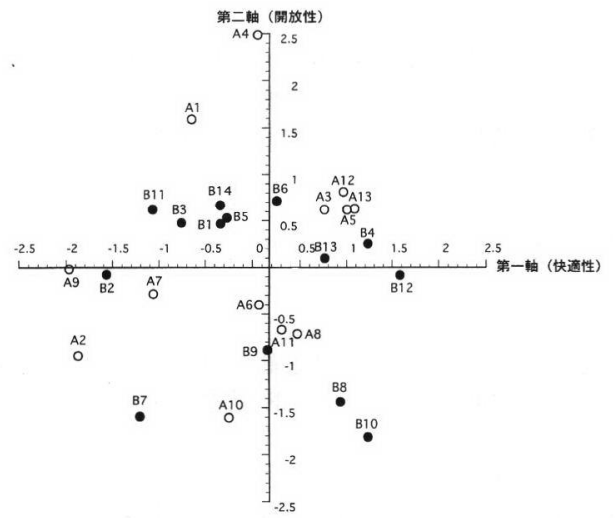

図-3 第一因子軸と第二因子軸上の景観代表写真の配置
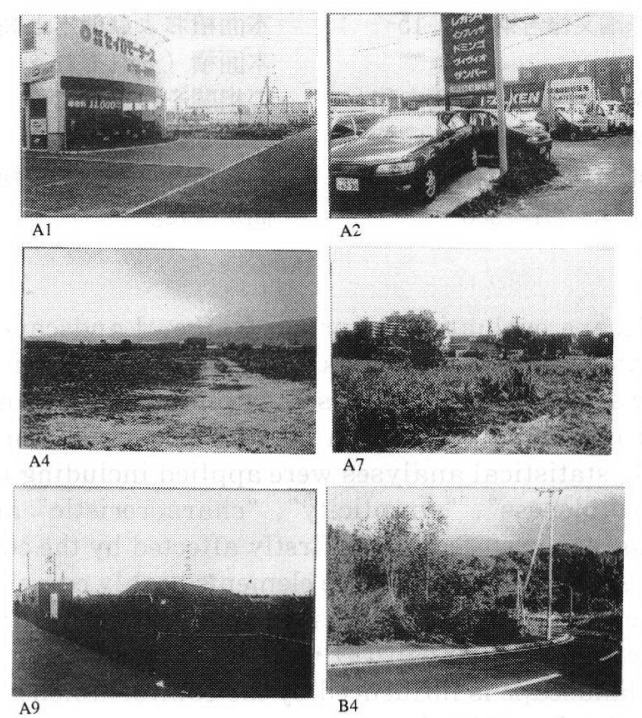
A2

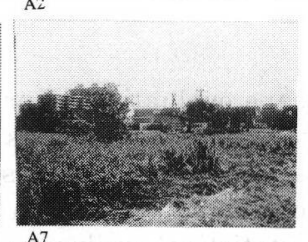

A7

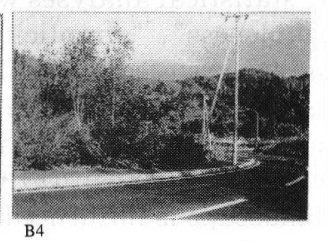

写真-1 景観代表写真 例 景観構成要素の面積比率（arcsin 変換後）と因子軸之の相関 を求めたところ, 表一 4 の結果が得られた。

快適性因子は低木の面積と正の相関を持った。開放性因子は山 や荒れ地の面積と正の相関を持ち, 人工物の面積と負相関を示し た。また, 特徴性因子は高木の面積と正相関を示し, 住宅や雑草 地の面積と負相関を示した。単調性はどの景観構成要素に対して も相関はなかった。

\section{（5）因子得点軸空間での景観配置}

重回帰分析の結果，嗜好性に対して有意な影響力を持った第一 軸から第三軸までの各因子得点軸空間に景観代表写真を配置し, 写真毎の特徴をみた (図 $-3,4$, 写真 -1 )。

快適性因子軸（第一軸）上で最む快適な景観はB 地区の B 12, B 4 とB10であり, 最も不快な景観はA地区のA 9 とA 2 であっ た。B12 は林縁であり, B 4 は道路脇の雑木林が左側を占有し, B10 は低木が植栽された住宅の庭であり, いずれも緑量の多い 景観であった。逆に, 最も不快な景観はA 9 の資材置き場であり, A 2 の中古車展示場であった。

開放性因子軸（第二軸）上に配置された最む開放的な景観は $\mathrm{A}$ 地区の A 4 とA 1 であり, 最む閉鎖的な景観はB 地区の B 10, B 7 と B 8 であった。A 4 は遠景に山が広がる人工物のない荒地で あり, A 1 は商店の駐車場であった。また, B 10, B 7 と B 8 は いずれむ住宅のが゙や塀が視界を妨げていた。

特徵性因子軸（第三軸）についてみる之, 最も特徵的な景観は B地区のB14 とB13 であり, 逆に最む平凡な景観は A 地区の A

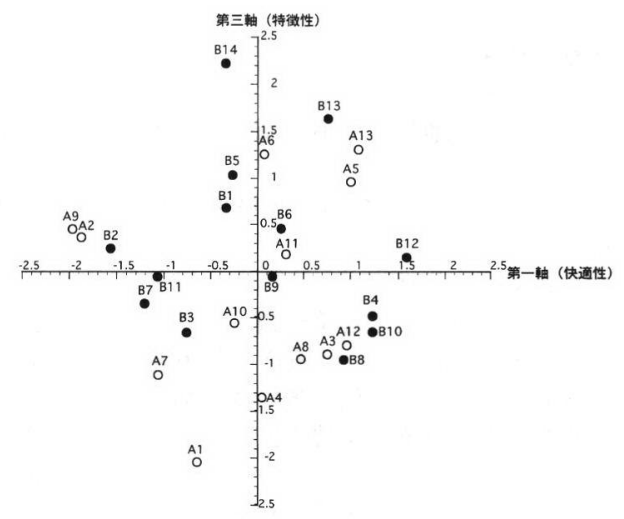

図-4 第一因子軸と第三因子軸上の景観代表写真の配置
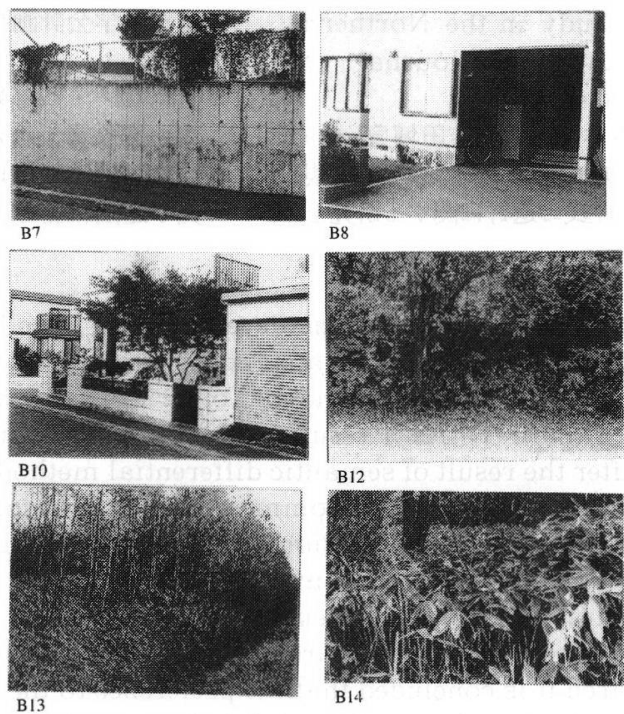

Bla 西

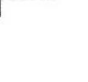


1, A 4 とA 7 であった。B 14 は林床に密生するササ群落であ り, B13 は雑木林とその林縁であり, いずれも住宅や雑草地は 見られなかった。最む平凡な A 1 は商店の駐車場であり, 左に建 物があった。また, A 4 は雑草地と荒地であり, A 7 は近景が雑 草地であり, 中景を住宅地が占めていた。

\section{5. 考察}

レパートリーグリッド発展法による分析の結果, A・B両地区 とも緑の多さが好ましい景観の評価項目としてあげられた。この ことは因子分析の結果にも現れており，好ましい景観に貢献する 快適性因子と特徵的因子について, 低木量が快適性を高め, 高木 量が特徴性を高めていた主2)。一方, 増田らの研究では, 緑の豊 かさに対する評価では低木の緑量が高木の緑量とほぼ同程度影響 するが他の評価項目に対しては, 高木の緑量の方が低木の緑量に 比較して影響度合いが大きいことを明らかにしている ${ }^{12}$ 。この結 果の違いについて, 増田らの研究が歩道空間を構成する街路樹を 対象にしているのに対し, 本研究では遠景の田園風景が遮断され ていないという環境の違いが結果に大きく影響していると推察さ れる。また都市部での増田らの研究に比べ, アーバンフリンジで の本研究では緑量以外の景観構成要素の違いが結果に大きく影響 していると推察される。

また, 特徵性因子軸について, 雑草地や住宅が平凡と捉えられ ているのは居住地環境の現況によるところが大きいと考えられる。 評価項目間の関係を $\mathrm{A}$ 地区, B地区にみると, A 地区の方が開 放的であるという特徴を持った。このことは因子分析の結果にも
反映されており，開放性のきわめて高かった景観は A 地区に集 中していた。A地区のなかで特に開放性の高かった景観は人工物 が少なく遠景に山稜が眺望できる景観であった。

また，好ましい景観に貢献する快適性や特徴性が特に高い景観 はB地区にみられた。

今回, 農地景観が景観評価に大きく影響を与えなかった。この 理由として李らやAsakawa らの研究に対し, 景観代表写真に 農地が含まれる写真が少ないことが影響していると考えられる ${ }^{4) 5} 。$ 以上の分析結果から, 今後アーバンフリンジにおける現況の景 観評価に関して，以下のような示唆を得た。1）評価項目とその 構造の分析結果から，特に緑の量が景観評価に大きな影響を与え ていた。2）分析結果から，景観を評価する際には快適性・開放 性・特徵性の順に有意な影響力を持っていた。3）快適性因子軸 に大きな影響を与える景観構成要素として, 低木があげられる。 また特徵性を示す評価因子軸には，高木・住宅・雑草地が，開放 性因子軸には山・人工物・荒地がそれぞれ影響を与えることがわ かった。

\section{謝辞 \\ 札幌市立高等専門学校及び北海道大学の学生，(株)北海道技術コ ンサルタント, (社)北海道都市再開発促進協会の皆様には, 調查 に対し多大なご協力を頂いた。また京都大学大学院吉田博宣教授, 札幌市宮浦哲也係長には資料の提供をして頂いた。この場をお借 りして感謝の意を表したい。なお本研究は一部(財)第一住宅建設 協会の助成を受けて行われた。}

\section{参考文献・補注}

1 ）波多野憲男（1995）: アーバンフリン ジにおける土地利用計画課題：都市 計画 $195,39-43$

2 ）札幌市（1999）：札幌市市政概要：札 幌市, 26-27

3 ）波多野憲男・若林祥文（1994）: 都市 近郊土地利用事典 : 建築知識, 9

4) 李洪秦・進士五十八 (1995)：都市農 地景観のイメージ評価と喍好度に関す る研究: 東京農業大学農学集報 39(4), 290-297

5 ) Asakawa S., Aikoh T. \& Kim S. (1997) : Visual Assessment of Urban Fringe Landscape-Based on a Case Study in the Northern Part of Sapporo- : Journal of Urban Studies34 : 1-7.

6) アリスティムニョ I.・吉田博宣（19 95）: 神戸市アーバンフリンジの景観 变化に対する住民の選好に関する研究：
ランドスケープ研究 58(5), 249-252

7 ）グアナン A・吉田博宣 (1988)：ボゴー ル市アーバンフリンジの景観と土地利 用に関する住民の意識について：造園 雑誌 57(5)，367-372

8 ）札幌市（1997）: 札幌市都市景観基本 計画 : 札幌市

9 ) 長峰麻衣子（1997）: 市街地周辺部に おける土地利用之景観の関連性につい て一札幌市北部を事例として一：北海 道大学農学部卒業論文

10）讃井純一郎・乾正雄（1986）：レパー トリー・グリッド発展手法による住環 境評価構造の抽出一認知心理学に基づ く住環境評価に関する研究 (1) - : 日 本建築学会計画系論文報告集 $367,15-$ 22

11）磯野順一・斎藤馨・熊谷洋一・武内和 彦・輿水肇・山本幹夫 (1990)：丘陵 地における住宅地景観評価に関する研 究 : 造園雑誌 53(5), 251-256
12）増田昇 - 下村恭彦・安部大就 (1989): 都市景観形成に係る街路緑化手法に関 する研究 : 造園雑誌 52(5), 318-323

注 1 ）レパートリーグリッド発展法の目的 は，コンストラクトシステムのうち環 境評価構造だけを効率的よく抽出すこ とである。従来のレパートリーグリッ ド法に比べ, エレメント（今回の実験 では景観写真）間の優少を判断させ, その判断基準に焦点をあて, 評価項目 だけを選択的に言語化し, 抽出するこ とができるとするものである。また評 価項目間の因果関係を明らかにする為, ラダーリング手法も導入している10)。 注 2 ）さらに快適性因子軸と低木面積, 高 木面積および低木と高木を合わせた樹 木面積（それぞれ $\arcsin$ 変換後）と の相関をみたところ, 相関係数はそれ ぞれ $0.5811,0.362,0.432$ であり，低木 の面積と快適性因子軸との相関が最も 高かった。

Summary: A prominent theme is the development of landscape evaluation of urban fringe. Landscape evaluation is concerned with the planning and management influenced by landscape elements and criteria in decision making. 27 pictures of two districts (one low land and other hill side) were chosen for this research on the urban fringe in Sapporo City, northern Japan. 1) As a result of the evaluation grid method, there is a positive preference for a richness of greenery. 2) After the result of semantic differential method, statistical analyses were applied including factor analysis and principle component. The four common factors "comfortableness", "simplicity", "characreristic" and "openness" are identified. 3) A multiple regression analysis revealed that the preference was firstly affected by the comfortableness variate, secondly by openness and thirdly characteristic. 4) Analysis on landscape elements highly correlated with three variates was identified. Comfortableness - shrub (positive correlation). Openness-mountain (positive) • barren(positi ve) $\cdot$ house (negative) $\cdot$ small structure (negative). Characteristic- tree (positive) $\cdot$ house (negative) $\cdot$ grass (negative). From this research it is concluded that the preference to the landscape is influenced by the comfortableness variate. And especially the landscape element "shrub" influences the total value of landscape. 